\title{
Low rates of enteric pathogenic bacteria and resistance gene carriage in the sheltered homeless population in Marseille, France
}

Tran Duc Anh Ly ${ }^{1,2}$, Linda Hadjadj ${ }^{2,3}$, Van Thuan Hoang ${ }^{1,2,4}$, Ndiaw Goumbala ${ }^{1,2,5}$, Thi Loi Dao $^{1,2,6}$, Sekene Badiaga ${ }^{2,7}$, Herve Tissot-Dupont ${ }^{2,3}$, Philippe Brouqui ${ }^{2,3}$, Didier Raoult ${ }^{1,2,3}$, JeanMarc Rolain ${ }^{2,3}$ and Philippe Gautret ${ }^{1,2 *}$

1. Aix Marseille Univ, IRD, AP-HM, SSA, VITROME, Marseille, France.

2. IHU-Méditerranée Infection, Marseille, France.

3. Aix Marseille Univ, MEPHI, Marseille, France.

4. Pneumology Department, Thai Binh University of Medicine and Pharmacy, Vietnam

5. VITROME, Campus International IRD-UCAD de l'IRD, Dakar, Senegal

6. Family Medicine Department, Thai Binh University of Medicine and Pharmacy, Vietnam

7. Aix Marseille Univ, Service des urgences CHU Hôpital Nord

*Corresponding author: Philippe Gautret, VITROME, Institut Hospitalo-Universitaire Méditerranée Infection, 19-21 Boulevard Jean Moulin 13385 Marseille Cedex 05, France. Phone: +33(0) 4137324 01. Fax: + 33 (0) 413732402 .

Email address: philippe.gautret@club-internet.fr 


\begin{abstract}
We aimed to assess the prevalence of pathogenic bacteria and resistance genes in rectal samples collected among homeless persons in Marseille, France. In February 2014 we enrolled 114 sheltered homeless adults who completed questionnaires and had rectal samples collected. Eight types of enteric bacteria and 15 antibiotic resistance genes (ARGs) were sought by real-time polymerase chain reaction (qPCR) performed directly on rectal samples. ARG-positive samples were further tested by conventional PCR and sequencing. We evidenced a $17.5 \%$ prevalence of gastrointestinal symptoms, a 9.6\% DNA-prevalence of enteric bacteria carriage, including Escherichia coli pathotypes (8.7\%) and Tropheryma whipplei $(0.9 \%)$. Only 2 persons carried bla $a_{\text {СТХ-M-15 }}$ resistance genes $(1.8 \%)$, while other genes, including carbapenemase-encoding genes and colistin-resistance genes, ( $m$ cr -1 to $m c r-6, m c r-8)$ were not detected. Our results suggest that sheltered homeless persons in Marseille do not have a high risk of harbouring gastrointestinal antibiotic resistant bacteria.
\end{abstract}

Keywords: antibiotic resistance gene; enteric bacteria; homeless; real-time polymerase chain reaction $(\mathrm{qPCR})$ 


\section{Introduction}

Little information is available about gastrointestinal bacterial infections in homeless populations. During 2015-2016 a multistate outbreak of Shigella occurred among homeless persons in Oregon, USA. There, the homeless accounted for half of cases [1,2]. Shigella was also responsible for an outbreak occurring among homeless persons and healthcare workers in a homeless shelter in British Columbia, Canada, in 2015 [3]. A survey conducted in Georgia, USA in 2018 reported a high prevalence (23\%) of enteric pathogens in homeless individuals' stools open-defecated on the street, including enterotoxigenic Escherichia coli (12\%) and Salmonella spp. (3.8\%), posing health risks to the general public [4]. Other than these enteric bacteria, Mycobacterium tuberculosis (causing gastrointestinal tuberculosis), hepatitis A virus and many intestinal parasitic infections have been described in homeless populations [5-10].

Given the lack of surveillance due to the high mobility of this population, antimicrobial resistance (AMR), if occurring in the homeless population, can challenge local health care systems. Production of specific inactivating enzymes (such as extended-spectrum $\beta$-lactamases [ESBLs] and carbapenem-hydrolysing $\beta$-lactamases) is considered the most important mechanism contributing to antimicrobial resistance to $\beta$-lactam antibiotics in gram-negative bacteria [11]. Colistin is currently prescribed as one of the last-line antibiotics for treatment of a variety of human infections; nevertheless, the emergence of plasmid-mediated colistin resistance genes, such as the $m c r-1$ gene, has also been globally observed [12]. Few studies are available regarding the prevalence of enteric pathogens resistant to antibiotics in this population. A high prevalence (75\%) of bla $a_{\text {CTX-M-15 }}$ was evidenced in 36 ESBL-producing Enterobacteriaceae isolated from stools of Tanzanian street children that were phenotypically resistant to tetracycline (100\%), trimethoprim-sulfamethoxazole (97\%), ciprofloxacin $(69 \%)$ and gentamicin (44\%) [13]. 
Surveys have been conducted by our institute among homeless persons within two shelters (A and B) in Marseille, France, between 2010 and 2011 and showed a high prevalence (12.9\%) of Trpheryma whipplei in homeless persons' stool samples [14]. Gastrointestinal infections were diagnosed in $6 \%$ of hospitalised homeless persons at the infectious disease units in Marseille, France between 2017-2018[15]. In a previous work, using direct molecular detection, we observed a lower prevalence of resistance genes in nasal swabs in sheltered homeless in Marseille when compared to a non-homeless population [16]. In this cross-sectional study, using the same approach, we aimed to assess the prevalence of several gastrointestinal pathogens DNA and resistance genes carriage in the sheltered homeless in Marseille.

\section{Materials and Methods}

\section{Ethics approval and informed consent.}

This protocol was reviewed and approved by the Marseille Institutional Review Board/Ethics Committee (Homeless population: 2010-A01406-33; Comparison group: 07-008-IFR 48). Informed consent was dated and signed by all individuals.

\section{Study design and sample collection}

Data and rectal swab samples were obtained from adult homeless persons living in two municipal emergency shelters A and B in Marseille, France on 11-13 March and 11 April, 2014, respectively. The participants were asked to answer a questionnaire, including information on demographics, personal history, clinical gastrointestinal symptoms, including diarrhoea (defined as at least three loose or liquid stools per 24 hours), vomiting, nausea, constipation and abdominal pain. Rectal swab samples were collected and stored as previously described [17].

\section{DNA extraction}

Semi-automated DNA extraction was performed on $200 \mu$ l of each sample as previously described [18] using a BioRobot@EZ1 Advanced XL instrument (QIAGEN, Hilden, Germany) 
and DNeasy ${ }^{\circledR}$ Blood \& Tissue according to the manufacturer's instructions. The DNA extraction quality was assessed by RT-PCR targeting internal control TISS phage that was added to each extraction [19].

\section{Real-time PCR}

\section{Identification of enteric bacteria}

A multiplex PCR-based assay using LightCycler®480 Probes Master kit (Roche diagnostics, France, according to the manufacturer's recommendations) was used to determine the presence of the ipaH gene of Shigella spp./EIEC (enteroinvasive E. coli), stx1 and stx2 genes of enterohaemorrhagic E. coli (EHEC), EAF and EAE genes of enteropathogenic E. coli (EPEC), pCVD432 gene of enteroaggregative E. coli (EAEC), mapA gene of Campylobacter jejuni, Twhip2 gene of T. whipplei and invA gene of Salmonella spp.

\section{Identification of resistance genes}

Real-time PCR (qPCR) amplifications were carried out using a C1000 Touch $^{\mathrm{TM}}$ Thermal Cycle (Bio-Rad, USA) with the ready-to-use reaction mix ROX qPCR Master according to the manufacturer's recommendations. The qPCR amplification was used to confirm the presence of (i) ESBL genes: $b l a_{\mathrm{CTX}-\mathrm{M}-\mathrm{A}}$ and $\operatorname{bla}_{\mathrm{CTX}-\mathrm{B}}\left(\right.$ bla $_{\mathrm{CTX}-\mathrm{M}}$ cluster $\mathrm{A}$ and $\left.\mathrm{B}\right)$ and carbapenemaseencoding genes: bla $\mathrm{OXA}_{-23}, b l a_{\mathrm{OXA}-24}, b l a_{\mathrm{OXA}-48}, b l a_{\mathrm{OXA}-58}, b l a_{\mathrm{NDM}}, b l a_{\mathrm{VIM}}, b l a_{\mathrm{KPC}}$ and (ii) colistin-resistance genes: $m c r-1, m c r-2$ (including $m c r-6$ ), $m c r-3, m c r-4, m c r-5$ and $m c r-8$, by using primers as described and by using specific primers designed in our laboratory (Table 1) $[16,21-26]$.

\section{Amplification procedure and experimental validation}

Negative control (single PCR mix \& sterile $\mathrm{H}_{2} \mathrm{O}$ ) and a positive control template (Plasmid DNA extracted from bacterial strains [for enteric pathogens]) or from a colony of cultured Acinetobacter baumannii, E. coli or Klebsiella pneumoniae [for resistance genes] were included 
in each qPCR experimental run. Positive results were defined as those with a cycle threshold (CT) value $\leq 35$.

Conventional PCR and sequencing. To better characterize resistance genes, only positive qPCR samples were further tested by conventional PCR. Positive bla $a_{\mathrm{CTX}-\mathrm{M}-\mathrm{A}}$ samples were

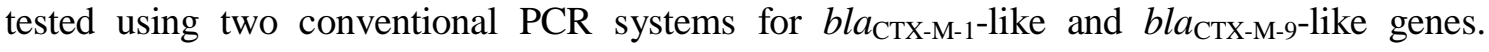
Positive bla $_{\mathrm{CTX-B}}$ samples were tested using two conventional PCR systems for bla $_{\mathrm{CTX}-\mathrm{M}-2 \text {-like }}$

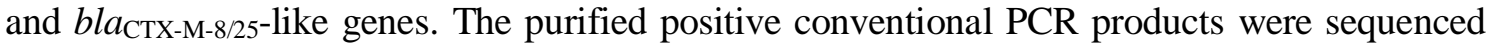
using specific primers and the BigDye Terminator ${ }^{\circledR}$ version 1.1 cycle sequencing ready reaction mix (Applied Biosystems, Foster City, CA). The sequencing reactions were purified with SephadexG-50 Superfine on MAHVN 45-50 plates (Millipore, Molsheim, France) and then sequenced on the Applied Biosystems 3130 platform (ABI PRISM, PE Applied Biosystems, USA). For each gene, the sequences obtained were edited and assembled using Chromas Pro1.7.7 software (Technelysium Pty Ltd, Australia) and were then aligned with reference genes from the ARG-ANNOT by Mega 7.0 software (https://www.megasoftware.net) [27]. These sequences are available in GenBank at accession numbers MT215959 and MT215960 (for $b l a_{\text {СTХ-M-A }}$ (Figure 1).

\section{Statistical analysis.}

Statistical procedures were performed using STATA 11.1 software (StataCorp LLC, USA). Statistical differences in baseline characteristics were evaluated by Pearson's chi-square or Fisher's exact tests as categorical variables. A two-tailed p-value $<0.05$ was considered as statistically significant. The odds ratio (univariate analysis) was used to examine associations between the presence of bacterial pathogen DNA and enteric symptoms or migrant status.

\section{Results}

\section{Population characteristics (Table 2 and Figure 2).}


Overall, 114 homeless persons were included in the study and provided rectal samples. The homeless individuals were predominantly middle-aged males, mostly originating from North Africa who settled in France approximately 10 years before the survey was done. The mean duration of homelessness was about 4 years. Overweight status was reported in 48 individuals $(44.9 \%)$, and obesity in 8 individuals $(7.5 \%)$.

About $17.5 \%(\mathrm{n}=20)$ declared having at least one gastrointestinal symptom at enrolment, with abdominal pain the most frequent. One participant (0.9\%) had fever. None was hospitalized.

\section{Screening for enteric bacteria (Table 3)}

We recorded a $9.6 \%$ prevalence of rectal carriage of bacterial DNA $(n=11)$, with EHEC and EPEC the most frequent. Of positive individuals, seven were born in Algeria, two in France, one in Italy and one in Pakistan. No significant association between carriage of pathogens and gastrointestinal symptoms (odds ratio=1.9 $[0.5-7.9], \mathrm{p}=0.4)$ or being a migrant $(\mathrm{OR}=1.0[0.2-$ 5.0], $\mathrm{p}=1.0$ ) was found.

\section{Screening for resistance genes (Table 4 and Figure 1)}

Only two individuals $(1.8 \%)$ were positive for $b l a_{\mathrm{CTX}-\mathrm{M}-\mathrm{A}}(\mathrm{qPCR})$. These two individuals tested negative for bacterial pathogen DNA. Both individuals were further positive for $b l a_{\mathrm{CTX} \text {-M-1-like }}$ genes (conventional PCR). Both were recruited from shelter A, were from Algeria, having been in France for less than six months and having experienced homelessness for less than five months. These two sequences showed $100 \%$ nucleotide identity to bla $a_{\mathrm{CTX}-\mathrm{M}-15 \text {-like }}$ type/reference gene at the ARG-ANNOT site.

None of the samples tested positive for $b l a_{\mathrm{CTX}-\mathrm{M}-\mathrm{B}}$, carbapenemase-encoding genes and colistin-resistance genes.

\section{Discussion}


This is the first retrospective study aiming to assess the carriage of a panel of bacterial pathogen DNA and resistance genes in rectal samples from sheltered homeless persons in Marseille. We found relatively low rates of $E$. coli pathotype genes (8.7\%). The prevalence of $E$. coli DNA carriage was $24.2 \%$ among pre-Hajj pilgrims (before departing from Marseille) in the summer between 2016-2018 (unpublished data) [28] and 13.5\% among medical students before travelling abroad in the summer 2018-2019 (unpublished data).

One subject only tested positive for T. whipplei $(0.9 \%)$, which is much lower than the $12.9 \%$ prevalence observed in 2010-2011 in Marseille sheltered homeless stool samples [14]. A possible explanation for the low rates of pathogen DNA in the present study is that it was carried out in winter, since it was demonstrated that seasonal variations have impacted the enteric microbial community in adults and children [29-30]. Future studies will be conducted at least twice a year (in winter and in summer) to challenge this hypothesis.

Overall, a very low prevalence of resistance gene carriage was observed among homeless individuals, with only two individuals (1.8\%) carrying bla ${ }_{C T X-M-15}$ genes. In surveys conducted among French pilgrims before departure to the Hajj pilgrimage in the years 2013-2014, the prevalence of bla CTX-M $_{M}$ was $9.2 \%$ when detected in rectal samples by the same molecular method [31]. Our result is in accordance with a low prevalence of resistance gene carriage found in respiratory samples among Marseille homeless persons in 2018. Our work has several limitations. Homeless participants were not randomly selected, so that those harbouring gastrointestinal symptoms might have been more prone to enroll in the survey, given that a medical examination was offered. Viral and parasite pathogens were not tested in this study. Information about recent antibiotic use prior to testing was not documented. The detection of resistance genes directly from rectal samples did not allow identifying the bacteria that housed the antibiotic resistance genes. Despite these limitations, this preliminary study evidenced a 
medRxiv preprint doi: https://doi.org/10.1101/2020.09.22.20199729; this version posted September 24, 2020. The copyright holder for this preprint (which was not certified by peer review) is the author/funder, who has granted medRxiv a license to display the preprint in perpetuity.

It is made available under a CC-BY-NC-ND 4.0 International license .

relatively low rate of both gastrointestinal pathogen DNA and resistance gene carriage among sheltered homeless persons in Marseille, suggesting that the homeless do not have a high risk of harbouring gastrointestinal antibiotic resistant bacteria. 


\section{Competing interests.}

No conflict of interest was reported by the authors.

\section{Acknowledgments}

This study was supported by the Institut Hospitalo-Universitaire (IHU) Méditerranée Infection, the National Research Agency under the program "Investissements d'avenir", reference ANR10-IAHU-03, the Région Provence Alpes Côte d'Azur and European funding FEDER PRIMI. We thank our colleagues for their technical assistance.

\section{Authors' contribution.}

TD, JMC and PG contributed to experimental design, data analysis, statistics, interpretation and writing. TD, VT, TL, SB, HTD administered questionnaires, examined patients and collected samples. LH, ML provided technical assistance. DR, JMR contributed to critically reviewing the manuscript. PG coordinated the work. 


\section{References}

1. Hines JZ, Pinsent T, Rees K, Vines J, Bowen A, et al. Notes from the Field: Shigellosis Outbreak Among Men Who Have Sex with Men and Homeless Persons - Oregon, 20152016. MMWR Morb Mortal Wkly Rep 2016;65(31):812-813.

2. Hines JZ, Jagger MA, Jeanne TL, West N, Winquist A, et al. Heavy precipitation as a risk factor for shigellosis among homeless persons during an outbreak - Oregon, 2015-2016. J Infect 2018;76(3):280-5. Doi: 10.1016/j.jinf.2017.11.010

3. Murti M, Louie K, Bigham M, Hoang LMN. Outbreak of Shigellosis in a Homeless Shelter With Healthcare Worker Transmission-British Columbia, April 2015. Infect Control Hosp Epidemiol 2015;36(11):1372-1373.

4. Capone D, Ferguson A, Gribble MO, Brown J. Open Defecation Sites, Unmet Sanitation Needs, and Potential Sanitary Risks in Atlanta, Georgia, 2017-2018. Am J Public Health 2018;108(9):1238-1240.

5. Sheer TA, Coyle WJ. Gastrointestinal tuberculosis. Curr Gastroenterol Rep 2003;5(4):273278.

6. Doshani M, Weng M, Moore KL, Romero JR, Nelson NP. Recommendations of the Advisory Committee on Immunization Practices for Use of Hepatitis A Vaccine for Persons Experiencing Homelessness. MMWR Morb Mortal Wkly Rep 2019;68(6):1536.

7. Zenu S, Alemayehu E, Woldemichael K. Prevalence of intestinal parasitic infections and associated factors among street children in Jimma town; south West Ethiopia in 2019: a cross sectional study. BMC Public Health 2019;19(1):1731. 
8. Moges F, Kebede Y, Kassu A, Degu G, Tiruneh M, et al. Infection with HIV and intestinal parasites among street dwellers in Gondar city, northwest Ethiopia. Jpn J Infect Dis 2006;59(6):400.

9. Gomes TC, Almeida MF, Miura LA, Granja J, Santos DVG, et al. Helmintoses intestinais em população de rua da cidade do Rio de Janeiro [Intestinal helminthiasis in street population of Rio de Janeiro city]. Rev Soc Bras Med Trop 2002;35(5):531-532.

10. Bass JL, Brennan P, Mehta KA, Kodzis S. Pediatric problems in a suburban shelter for homeless families. Pediatrics 1990;85(1):33-38.

11. Munita JM, Arias CA. Mechanisms of antibiotic resistance. Microbiol Spectr 2016;4:2.

12. Hadjadj L, Riziki T, Zhu Y, Li J, Diene S, Rolain J-M. Study of $m c r-1$ Gene-mediated colistin resistance in Enterobacteriaceae isolated from humans and animals in different countries. Genes 2017;8:394.

13. Moremi N, Claus H, Vogel U, Mshana SE. Faecal carriage of CTX-M extended-spectrum beta-lactamase-producing Enterobacteriaceae among street children dwelling in Mwanza city, Tanzania. PLoS One 2017;12(9):e0184592.

14. Keita AK, Brouqui P, Badiaga S, Benkouiten S, Ratmanov P, et al. Tropheryma whipplei prevalence strongly suggests human transmission in homeless shelters. Int J Infect Dis 2013;17(1):e67-68.

15. Ly TDA, Dao TL, Hoang VT, Braunstein D, Brouqui P, et al. Pattern of infections in French and migrant homeless hospitalised at Marseille infectious disease units, France: A retrospective study, 2017-2018. Travel Med Infect Dis 2020:101768. 
16. Ly TDA, Hadjadj L, Hoang VT, et al. Low prevalence of resistance genes in sheltered homeless population in Marseille, France, 2014-2018. Infect Drug Resist 2019;12:11391151.

17. Dao TL, Hoang VT, Ly TDA, Magmoun A, Canard N, et al. Infectious disease symptoms and microbial carriage among French medical students travelling abroad: A prospective study. Travel Med Infect Dis 2020;34:101548.

18. Menu E, Mary C, Toga I, Raoult D, Ranque S, et al. Evaluation of two DNA extraction methods for the PCR-based detection of eukaryotic enteric pathogens in fecal samples. BMC Res Notes. 2018;11:206.

19. Sow D, Parola P, Sylla K, Ndiye M, Delaunay P, et al. Performance of real-time polymerase chain reaction assays for the detection of 20 enteric parasites in clinical samples from Senegal. Am J Trop Med Hyg 2017;97:173-182.

20. AbuOun M, Stubberfield EJ, Duggett NA, Kirchner M, Dormer et al. $m c r-1$ and $m c r-2$ variant genes identified in Moraxella species isolated from pigs in Great Britain from 2014 to 2015. J Antimicrob Chemother 2017;72(10):2745-2749. Erratum in: J Antimicrob Chemother 2018;73(10):2904.

21. Chabou, S., T. Leangapichart, L. Okdah, S. Le Page, L. Hadjadj, et al. Real-time quantitative PCR assay with taqman $((\mathrm{R}))$ probe for rapid detection of $m c r-1$ plasmidmediated colistin resistance. New Microbes New Infect 2016;13:71-74.

22. Dandachi I, Fayad E, Sleiman A, Daoud Z, Rolain JM. Dissemination of MultidrugResistant and mcr-1 Gram-Negative Bacilli in Broilers, Farm Workers, and the Surrounding Environment in Lebanon. Microb Drug Resist 2020;26(4):368-377. 
23. Nabti LZ, Sahli F, Ngaiganam EP, Radji N, Mezaghcha W, et al. Development of realtime PCR assay allowed describing the first clinical Klebsiella pneumoniae isolate harboring plasmid-mediated colistin resistance mcr-8 gene in Algeria. J Glob Antimicrob Resist 2020;20:266-271.

24. Roschanski N, Fischer J, Guerra B, Roesler U. Development of a multiplex real-time PCR for the rapid detection of the predominant beta-lactamase genes CTX-M, SHV, TEM and CIT-type AmpCs in Enterobacteriaceae. PLoS One 2014;9(7):e100956.

25. Yu Y, Ji S, Chen Y, Zhou W, Wei Z, et al. Resistance of strains producing extendedspectrum beta-lactamases and genotype distribution in China J Infect 2007;54(1):53-57.

26. Strauß LM, Dahms C, Becker K, Kramel A, Kaase M, et al. Development and evaluation of a novel universal $\beta$-lactamase gene subtyping assay for blaSHV, blaTEM and blaCTXM using clinical and livestock-associated Escherichia coli. J Antimicrob Chemother 2015;70(3):710-715.

27. Gupta SK, Padmanabhan BR, Diene SM, Rojas RL, Kempf M, et al. ARG-ANNOT, a new bioinformatic tool to discover antibiotic resistance genes in bacterial genomes. Antimicrob Agents Chemother 2014; 58 :212-220.

28. Sow D, Dogue F, Edouard S, Drali T, Prades S, et al. Acquisition of enteric pathogens by pilgrims during the 2016 Hajj pilgrimage: A prospective cohort study. Travel Med Infect Dis 2018;25:26-30.

29. Larrosa-Haro A, Macias-Rosales R, Sánchez-Ramírez CA, Cortés-López MC, AguilarBenavides S. Seasonal variation of enteropathogens in infants and preschoolers with acute diarrhea in western Mexico. J Pediatr Gastroenterol Nutr 2010;51(4):534-536. 
medRxiv preprint doi: https://doi.org/10.1101/2020.09.22.20199729; this version posted September 24, 2020. The copyright holder for this preprint (which was not certified by peer review) is the author/funder, who has granted medRxiv a license to display the preprint in perpetuity.

It is made available under a CC-BY-NC-ND 4.0 International license .

30. Alam M, Akhtar YN, Ali SS, Ahmed M, Atiq M, et al. Seasonal variation in bacterial pathogens isolated from stool samples in Karachi, Pakistan. J Pak Med Assoc 2003;53(3):125-129

31. Leangapichart T, Tissot-Dupont H, Raoult D, Memish ZA, Rolain JM, et al. Risk factors for acquisition of CTX-M genes in pilgrims during Hajj 2013 and 2014. J Antimicrob Chemother 2017;72(9):2627-2635. 
medRxiv preprint doi: https://doi.org/10.1101/2020.09.22.20199729; this version posted September 24, 2020. The copyright holder for this preprint (which was not certified by peer review) is the author/funder, who has granted medRxiv a license to display the preprint in perpetuity.

It is made available under a CC-BY-NC-ND 4.0 International license .

Table 1. Sequences of primers and probes used for real-time PCRs and conventional PCRs in this study

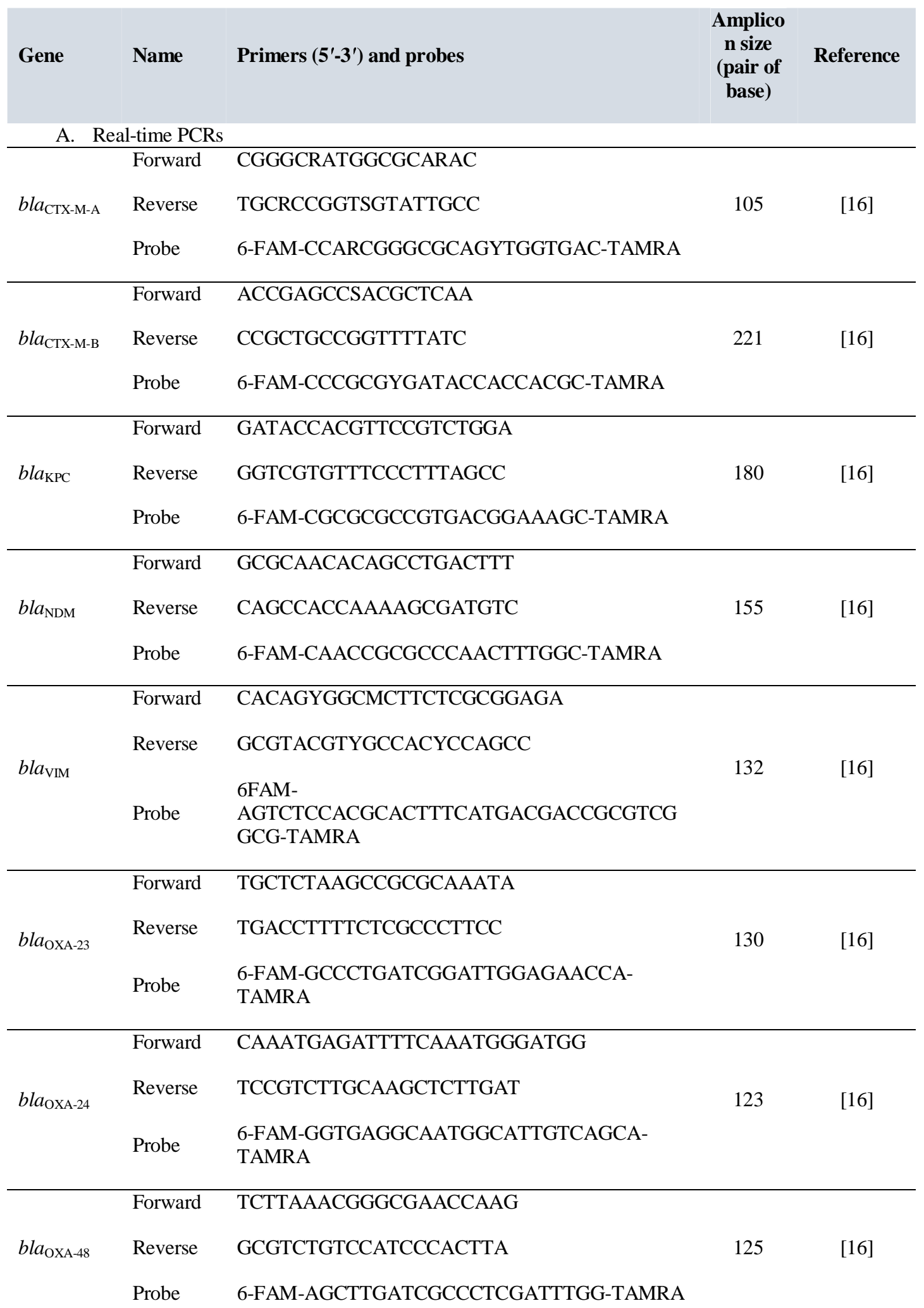


medRxiv preprint doi: https://doi.org/10.1101/2020.09.22.20199729; this version posted September 24, 2020. The copyright holder for this preprint (which was not certified by peer review) is the author/funder, who has granted medRxiv a license to display the preprint in perpetuity.

It is made available under a CC-BY-NC-ND 4.0 International license .

\begin{tabular}{|c|c|c|c|c|}
\hline \multirow{3}{*}{$b l a_{\text {OXA-58 }}$} & Forward & CGCAGAGGGGAGAATCGTCT & \multirow{3}{*}{102} & \multirow{3}{*}{ [16] } \\
\hline & Reverse & TTGCCCATCTGCCTTTTCAA & & \\
\hline & Probe & 6-FAM-GGGGAATGGCTGTAGACCCGC-TAMRA & & \\
\hline \multirow{3}{*}{$\begin{array}{l}m c r-1 \\
\text { (including } \\
m c r-7 \text { ) }\end{array}$} & Forward & GCAGCATACTTCTGTGTGGTAC & \multirow{3}{*}{145} & \multirow{3}{*}{ [21] } \\
\hline & Reverse & ACAAAGCCGAGATTGTCCGCG & & \\
\hline & Probe & $\begin{array}{l}\text { 6-FAM-GACCGCGACCGCCAATCTTACC- } \\
\text { TAMRA }\end{array}$ & & \\
\hline \multirow{3}{*}{$\begin{array}{l}m c r-2 \\
\text { (including } \\
\text { mcr-6) }\end{array}$} & Forward & CTGTGCCGTGTATGTTCAGC & \multirow{3}{*}{151} & \multirow{3}{*}{ [22] } \\
\hline & Reverse & TTATCCATCACGCCTTTTGAG & & \\
\hline & Probe & VIC-TGACCGCTTGGGTGTGGGTA-TAMRA & & \\
\hline \multirow{3}{*}{$m c r-3$} & Forward & TGAATCACTGGGAGCATTAGGGC & \multirow{3}{*}{144} & \multirow{3}{*}[22]{} \\
\hline & Reverse & TGCTGCAAACACGCCATATCAAC & & \\
\hline & Probe & $\begin{array}{l}\text { 6-FAM-TGCACCGGATGATCAGACCCGT- } \\
\text { TAMRA }\end{array}$ & & \\
\hline \multirow{3}{*}{$m c r-4$} & Forward & GCCAACCAATGCTCATACCCAAAA & \multirow{3}{*}{112} & \multirow{3}{*}{ [22] } \\
\hline & Reverse & CCGCCCCATTCGTGAAAACATAC & & \\
\hline & Probe & 6-FAM-GCCACGGCGGTGTCTCTACCC-TAMRA & & \\
\hline \multirow{3}{*}{$m c r-5$} & Forward & TATCCCGCAAGCTACCGACGC & \multirow{3}{*}{126} & \multirow{3}{*}{ [22] } \\
\hline & Reverse & ACGGGCAAGCACATGATCGGT & & \\
\hline & Probe & $\begin{array}{l}\text { 6-FAM-TGCGACACCACCGATCTGGCCA- } \\
\text { TAMRA }\end{array}$ & & \\
\hline \multirow{3}{*}{$m c r-8$} & Forward & TCCGGGATGCGTGACGTTGC & \multirow{3}{*}{158} & \multirow{3}{*}{ [23] } \\
\hline & Reverse & TGCTGCGCGAATGAAGACGA & & \\
\hline & Probe & $\begin{array}{l}\text { 6FAM-TCATGGAGAATCGCTGGGGGAAAGC- } \\
\text { TAMRA }\end{array}$ & & \\
\hline
\end{tabular}

\begin{tabular}{|c|c|c|c|c|}
\hline \multicolumn{5}{|c|}{ B. Conventional PCRs } \\
\hline$b l a_{\text {CTX-M-1- }}$ & Forward & CCCATGGTTAAAAAATCACTGC & \multirow{2}{*}{994} & \multirow{2}{*}{ [24] } \\
\hline & Reverse & CAGCGCTTTTGCCGTCTAAG & & \\
\hline \multirow{2}{*}{$\begin{array}{l}b l a_{\text {CTX-M-2- }} \\
\text { like }\end{array}$} & Forward & CTCAGAGCATTCGCCGCTCA & \multirow{2}{*}{843} & \multirow{2}{*}{25} \\
\hline & Reverse & CCGCCGCAGCCAGAATATCC & & \\
\hline \multirow{2}{*}{$\begin{array}{l}\text { bla }_{\text {CTX-M-9- }} \\
\text { like }\end{array}$} & Forward & GCGCATGGTGACAAAGAGAGTGCAA & \multirow{2}{*}{876} & \multirow[t]{2}{*}{ [25] } \\
\hline & Reverse & GTTACAGCCCTTCGGCGATGATTC & & \\
\hline$b^{\prime} l a_{\text {СTX-M- }}$ & Forward & CCAGGCGAACGATGTTCAACA & 730 & [26] \\
\hline
\end{tabular}


medRxiv preprint doi: https://doi.org/10.1101/2020.09.22.20199729; this version posted September 24, 2020. The copyright holder for this preprint (which was not certified by peer review) is the author/funder, who has granted medRxiv a license to display the preprint in perpetuity.

It is made available under a CC-BY-NC-ND 4.0 International license .

8/25-like

Reverse CGGCTCCGACTGGGTGAAGTA 
medRxiv preprint doi: https://doi.org/10.1101/2020.09.22.20199729; this version posted September 24, 2020. The copyright holder for this preprint (which was not certified by peer review) is the author/funder, who has granted medRxiv a license to display the preprint in perpetuity.

It is made available under a CC-BY-NC-ND 4.0 International license .

Table 2. Demographics and body mass index ( $\mathrm{N}=114$ individuals)

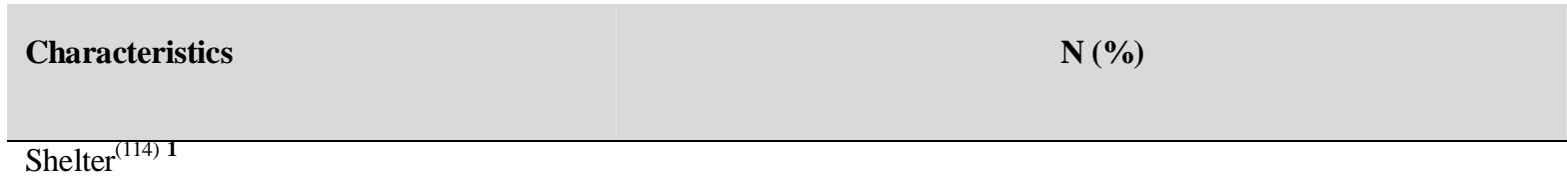

A

$69(60.5)$

B

$45(39.5)$

\begin{tabular}{cc}
\hline $\operatorname{Sex}^{(114)}$ & \\
Male & $103(90.4)$ \\
Female & $11(9.6)$
\end{tabular}

\begin{tabular}{|c|c|}
\hline $\operatorname{Age}^{(114)}$ & \\
\hline Mean age (SD) & $43.5 \pm 14.3$ \\
\hline Age range & $19-85$ \\
\hline$\leq 42$ years of age & $56(50.9)$ \\
\hline$>42$ years of age & $54(49.1)$ \\
\hline Unknown & $4(-)$ \\
\hline Birthplace $^{(110)}$ & \\
\hline France (mainland) & $20(18.2)$ \\
\hline Migrant & $90(81.8)$ \\
\hline North Africa & $63(57.3)$ \\
\hline Sub-Saharan Africa & $7(6.4)$ \\
\hline East Europe & $7(6.4)$ \\
\hline West Europe & $5(4.5)$ \\
\hline Asia & $8(7.2)$ \\
\hline $\begin{array}{l}\text { Mean duration of residence in France }{ }^{(112)} \\
\text { (SD) }\end{array}$ & $10.3 \pm 17.0$ years \\
\hline Range of duration of residence in France & $0-66$ years \\
\hline$\geq 1$ year & $45(51.1)$ \\
\hline$<1$ year & $43(48.9)$ \\
\hline
\end{tabular}


medRxiv preprint doi: https://doi.org/10.1101/2020.09.22.20199729; this version posted September 24, 2020. The copyright holder for this preprint (which was not certified by peer review) is the author/funder, who has granted medRxiv a license to display the preprint in perpetuity.

It is made available under a CC-BY-NC-ND 4.0 International license .

Range of duration of homelessness

$\geq 1$ year

$<1$ year

Body mass index ${ }^{(107)}$

Mean body mass index $( \pm \mathrm{SD})$

Range of Body mass index

Normal weight

Underweight

Overweight

Obesity
1 month -22 years

$54(50.5)$

$53(49.5)$

Abbreviations: SD, standard deviation;

${ }^{1}$ number of observations reported.

43 (40.2)

$8(7.5)$

48 (44.9)

8 (7.5) 
medRxiv preprint doi: https://doi.org/10.1101/2020.09.22.20199729; this version posted September 24, 2020. The copyright holder for this preprint (which was not certified by peer review) is the author/funder, who has granted medRxiv a license to display the preprint in perpetuity.

It is made available under a CC-BY-NC-ND 4.0 International license .

Table 3. Prevalence (\%) of gastrointestinal pathogen DNA detected by qPCR (N=114 individuals)

\begin{tabular}{|c|c|c|}
\hline Gastrointestinal pathogen & Tested gene & $\begin{array}{c}\text { Positive carriage } \\
\text { N (\%) }\end{array}$ \\
\hline At least one pathogen & & $11(9.6)$ \\
\hline Shigella spp/EIEC (enteroinvasive Escherichia coli) & ipaH & $0(0)$ \\
\hline Enterohaemorrhagic E. coli (EHEC) & stx 1 or $s t x 2$ & $5(4.3)$ \\
\hline Enteropathogenic E. coli (EPEC) & $E A F$ or $E A E$ & $4(3.5)$ \\
\hline Enteroaggregative $E$. coli (EAEC) & $p C V D 432$ & $2(1.8)$ \\
\hline Campylobacter jejuni & mapA & $0(0)$ \\
\hline Tropheryma whipplei & Twhip2 & $1(0.9)$ \\
\hline Salmonella spp. & $\operatorname{invA}$ & $0(0)$ \\
\hline At least one $E$. coli & & $10(8.7)$ \\
\hline \multicolumn{3}{|l|}{ Co-infection } \\
\hline $\mathrm{EPEC}+\mathrm{EHEC}$ & & $1(0.9)$ \\
\hline
\end{tabular}


medRxiv preprint doi: https://doi.org/10.1101/2020.09.22.20199729; this version posted September 24, 2020. The copyright holder for this preprint (which was not certified by peer review) is the author/funder, who has granted medRxiv a license to display the preprint in perpetuity.

It is made available under a CC-BY-NC-ND 4.0 International license .

Table 4. Prevalence of antibiotic resistance genes in rectal samples ( $N=114$ individuals)

\begin{tabular}{|c|c|}
\hline Overall gene frequency & $\mathbf{N}(\%)$ \\
\hline \multicolumn{2}{|l|}{ Extended-spectrum beta-lactamases } \\
\hline$b l a_{\mathrm{CTX}-\mathrm{M}-\mathrm{A}}{ }^{1}$ & $2(1.8)$ \\
\hline$b l a_{\text {СТХ-м-в }}$ & 0 \\
\hline Carbapenemase encoding genes & 0 \\
\hline$b l a_{\mathrm{OXA}-23}$ & 0 \\
\hline$b l a_{\text {OXA-24 }}$ & 0 \\
\hline$b l a_{\mathrm{OXA}-48}$ & 0 \\
\hline$b_{\text {OXA- } 58}$ & 0 \\
\hline$b l a_{\mathrm{KPC}}$ & 0 \\
\hline$b l a_{\mathrm{VIM}}$ & 0 \\
\hline$b l a_{\mathrm{NDM}}$ & 0 \\
\hline Colistin genes & $\mathbf{0}$ \\
\hline$m c r-1$ & 0 \\
\hline$m c r-2$ & 0 \\
\hline$m c r-3$ & 0 \\
\hline$m c r-4$ & 0 \\
\hline$m c r-5$ & 0 \\
\hline$m c r-8$ & 0 \\
\hline
\end{tabular}

${ }^{1}$ being all $b l a_{\mathrm{CTX}-\mathrm{M}-15}$ after sequencing 
medRxiv preprint doi: https://doi.org/10.1101/2020.09.22.20199729; this version posted September 24, 2020. The copyright holder for this preprint (which was not certified by peer review) is the author/funder, who has granted medRxiv a license to display the preprint in perpetuity.

It is made available under a CC-BY-NC-ND 4.0 International license .

Figure 1. Maximum likelihood phylogenetic tree of the diversity of $b l a_{\mathrm{CTX}-\mathrm{M}}$ resistance genes detected in rectal swabs from Marseille homeless people ( ). Phylogenetic inferences were conducted in MEGA 7 using the maximum likelihood method based on the Tamura-Nei model.

Figure 2. Prevalence of gastrointestinal symptoms ( $\mathrm{N}=114$ individuals) 

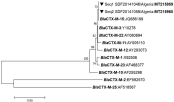


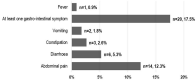

